\title{
Optimal water meter selection system
}

\author{
EH Johnson \\ Stewart Scott (Pty) Ltd, PO Box 25302, Monument Park 0105, South Africa
}

\begin{abstract}
The comparison of the particular accuracy envelope of a water meter with a consumer's diurnal demand pattern by means of a common reference facilitates the optimal selection of water meters.

The accuracy curve and envelope of a new water meter is governed by the type of water meter and relevant standards. Water demand patterns vary with time, period, seasons, consumers and combinations of these factors. The classical accuracy envelope and demand pattern are not directly comparable, and require a common comparison reference. The relative frequency of the volume of water passing through a meter at various flow rates and the weighted accuracies of these measured volumes play a pivotal role in establishing a common comparison reference.

The time unit selected to calculate the volume of water passing through the meter is guided by the type of water reticulation infrastructure within which the meter is installed. However, experience and literature show that a flow interval of less than 1 min would result in the application of unrealistic high flow rates.

A simplified example for the determination of the weighted accuracy of a water meter monitoring a theoretical demand pattern illustrates the methodology used to establish the common comparison reference.

Economic/financial analysis based on an income statement together with capital budgeting techniques assist with the determination of the financial suitability of investing in a new replacement water meter. This financial analysis includes various potential income and expenditure components that will result from the installation of a new water meter. Sensitivity analysis facilitates the decision-making process.

The analysis of flow data by a computer program developed in context with the described methodology illustrates that the savings achieved by the improved accuracy of matching the optimally selected meter and a particular demand profile can finance the costs of such an investment.
\end{abstract}

\section{Introduction}

The selection of a water meter for a required duty is complex and the consequences of an incorrect selection are loss of performance, time and money (British Standard BS 7405, 1991). A study undertaken in the United States found that generally water meters were oversized by some $50 \%$ when they were first installed (American Water Works Association, 1975) and a study for a South African coastal city found that nearly $65 \%$ of the water meters were oversized (Wild, 1997). Under-registration and a consequent loss of revenue are the result of poorly selected or improperly installed water meters (Jeffcoate and Pond, 1989).

The matching of theoretical water demand with the performance specification of a water meter is generally a common approach used by practitioners in the selection and sizing of a new water meter installation. Various codes or standards are used to establish these water demands in Britain (British Standard BS 6700, 1987), Germany (Coe, 1978) and South Africa (SABS 0252, 1994).

Water demands estimated by guidelines in South Africa such as the "Blue Book" (Department of Community Development, 1983) and "Red Book" (Department of Planning, Provincial Affairs and Housing, 1991) appear to over-estimate these water demands (Turner et al, 1997). Recent research has also identified that these South African guidelines over-estimate peak flows (Booyens, 2000).

This paper describes the theory used in the development and application of a module of a computerised optimal water meter selection system that utilises the actual water demand pattern recorded by an existing water meter for comparison with various

(012) 347-1018; fax: (012) 347-7379; e-mail: edgarj@ssi.co.za

Received 23 February 2001; accepted in revised form 30 May 2001. water meter performance specifications. The selection of a water meter that best "fits" the particular demand pattern is undertaken through a ranking process that considers the greatest weighted accuracy gain by the proposed meter, the minimum energy (head) loss and the lowest purchase price of the new meter. The final selection of the new meter is facilitated through the application of financial analysis techniques such as payback period, net present value (NPV) and internal rate of return (IRR).

\section{Accuracy curve and envelope}

Accuracy is the closeness of the actual reading to the true value and it includes the effect of both precision and bias error. Accuracy is greater when the indications are closer to the true value. Therefore, an accuracy of $99 \%$ is an inaccuracy of $1 \%$. However, inaccuracy (or error) is sometimes referred to as "accuracy" (Miller, 1989).

Accuracy envelopes are used to define the accuracy band within which the meter's accuracy curve is expected to be situated as well as its specified flow range.

The South African Standard Specification SABS 1529-1 (1994) as well as the International Standards ISO 4064 (1993) provide a generic definition of this accuracy envelope from the minimum flow rate $\left(\mathrm{q}_{\text {min }}\right)$ up to their maximum or overload flow rate $\left(\mathrm{q}_{\mathrm{s}}\right)$ as follows:

- $\mathrm{q}_{\min }$ is the lowest flow rate at which the meter is required to give indications within the permissible tolerance and is specified as a ratio of the permanent flow rate $\left(\mathrm{q}_{\mathrm{p}}\right)$ for various metrological classes of water meters.

- $\mathrm{q}_{\mathrm{p}}$ is the flow rate for which the meter is designed and at which the meter is required to give indications within the permissible tolerance under normal conditions of use. 


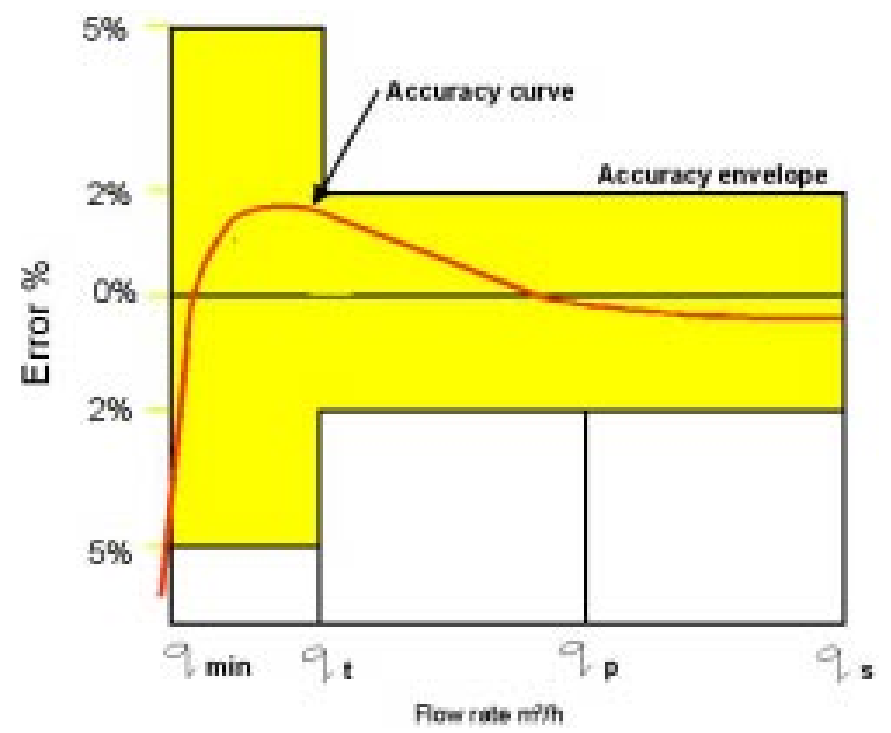

Figure 1

Typical accuracy curve and envelope (Meinecke, 1984)

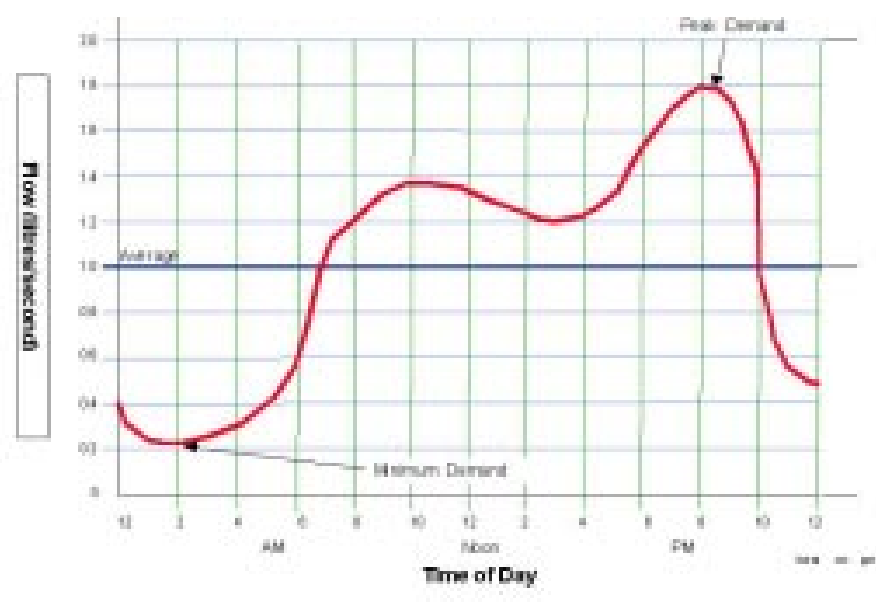

Figure 2

Example of a daily flow curve (AWWA, 1985)

- $\mathrm{q}_{\mathrm{s}}$ is the rate that is equal to $2 \mathrm{q}_{\mathrm{p}}$ and also represents the highest flow rate at which the meter is required to operate in a satisfactory manner for a short period of time without deterioration. This short period of time is specified by some manufacturers as $24 \mathrm{~h}$ in the life of the meter.

- Between $\mathrm{q}_{\min }$ and $\mathrm{q}_{\mathrm{p}}$, a transitional flow rate $\left(\mathrm{q}_{\mathrm{t}}\right)$ is specified dividing the flow range into two separate permissible tolerance zones.

- $\mathrm{q}_{\mathrm{t}}$ is also specified as a ratio of $\mathrm{q}_{\mathrm{p}}$ for various metrological classes of water meters.

$\mathrm{q}_{\mathrm{p}}$ is also referred to as $\mathrm{q}_{\mathrm{n}}$ and $\mathrm{q}_{\mathrm{s}}$ as $\mathrm{q}_{\max }$ in the International Standards ISO 4064 (1993).

A typical accuracy envelope and curve for a mechanical meter is illustrated in Fig. 1.

\section{Water demand (usage) pattern}

The amount of water demanded varies with the time of the day, day of the week and season of the year. Various types of consumers and combinations of these types can also influence a water demand pattern.
An example of a possible diurnal demand pattern for a residential area is illustrated in Fig. 2. Factors that affect water use listed by the American Water Works Association (1985) include the following:

- Time of day and day of week. The minimum demand usually occurs in the early hours of the morning when most people are asleep and maximum demand occurs in the early evening. In some developing communities in South Africa, the domestic water demands can be greater on a weekend than during the week because of migrant workers returning home on weekends (Van Schalkwyk, 1996).

- Climate and season of the year. Water demand is usually highest during summer months, particularly in warm, dry climates. The wetter the weather during a growing season of flora, the lower the seasonal demand for water in residential areas (Linaweaver et al., 1967). These seasonal variations in water demand can be defined by monthly factors (or ratios ) of the annual average consumption. Seasonal variations were described to within $0.5 \%$ with the aid of Time-Series Analysis as well as a Fourier Series function and associated confidence limits through the analysis of 11 years of water consumption data for Port Elizabeth (Johnson, 1987).

- User type. Residential communities generally use less water per person than highly commercialised communities. Demand patterns for industrial and commercial areas certainly differ from those that comprise predominantly residential dwellings (Turner et al., 1997).

Water demand patterns can also be influenced by technology such as household appliances in the domestic environment or automatic garden sprinkler systems. Technical adjustments in commercial and industrial establishments involving alterations to plant, ranging from installation of storage tanks, fitting of water flow regulators and removing of taps, to altering boiler systems or condensers have the most profound effect on reducing water demand and, therefore, changing their demand patterns (Schlemmer et al, 1969).

Time-Series Analysis can be used to establish both the deterministic and stochastic components of variations in the water demand pattern (Johnson, 1987). Typical deterministic components are those related to trend, cyclical and seasonal variations. The stochastic components are those irregular variations that could be caused by fire flows or other similar random events.

Large single user's demand patterns such as those for commercial buildings or industrial complexes are more amenable to assessment through field measurement than through theoretical predictions.

The computerised optimal water meter selection system allows for the seasonal adjustment of the actual water demand pattern that has been recorded for a short period. Seasonal adjustment factors, that have been determined by Time-Series Analysis, are used to adjust flow data logged during a specific time of the year, to be representative of the maximum for the year.

\section{Matching measured water demand patterns and meter specification through weighted accuracies}

The method adopted for the matching of actual water demand patterns, recorded by electronic data loggers, and a meter's performance specification is based on relative frequency curves and weighted accuracies.

The volume of water passing through the meter at various flow rates and for a selected time unit is calculated and then represented as a percentage of the total volume (for each flow rate range) of 
water passing through the meter during the monitoring period.

This approach plays a pivotal role in comparing water demand patterns and water meter accuracy envelopes to a common comparison reference.

The application of this methodology is illustrated through the use of flow data for the theoretical demand pattern given in Table 1. A one-hour time unit has been used to simplify the calculations for illustration purposes. However, in practice, different time-intervals are used for the various sections of the pipe network where the load (flow) should be considered to be constant.

Tessendorff(1972) recommended the time-intervals as follows:

$\begin{array}{ll}\text { For consumer installation lines: } & 15 \mathrm{~s} \\ \text { For service lines: } & 2 \mathrm{~min} \\ \text { For supply lines (and distribution systems): } & 15 \mathrm{~min} \\ \text { For mains and feeders: } & 30 \mathrm{~min}\end{array}$

Due to the technical limitations of the chart-scanning equipment used for Tessendorff's project, the limit of accuracy of the flow interval was $20 \mathrm{~s}$.

Buchberger and Wells (1996) recorded the total instantaneous water demand of a limited sample of domestic residences in the United States in order to establish the intensity, duration, and frequency of these demands. Using electronic data loggers that could record a minimum flow interval of $1 \mathrm{~s}$, the researchers found that nearly $98 \%$ of the total annual water consumed was for flow durations of more than $15 \mathrm{~s}$. On average, when a water demand occurred, it had a duration of about $1 \mathrm{~min}$.

Malan (1983) found that the duration of peak flows, for a small sample of domestic residences in South Africa, varied between 41 to $120 \mathrm{~s}$. The computerised optimal water meter selection system has the capability to process electronically logged data with a sampling interval selectable from $60 \mathrm{~s}$ to $60 \mathrm{~min}$.

The phenomenon of the shorter the duration with which peak flows are measured, the greater is the peak-flow (factor), has been described by Simpson (1989), Johnson (1999) as well as Booyens (2000). The use of shorter time-intervals than those suggested by Tessendorff would result in unrealistically high values being determined for the sizing of water infrastructure including water meters.

The percentage volume of water that coincides with the flow ranges for the performance specification of a particular water meter is then determined as illustrated in column 4 of Table 2 . The weighted accuracy of the particular water meter is established as the product of the error limits and percentage volume of water at those flow rates (column 4 of Table 2).

The weighted accuracy of the $80 \mathrm{~mm}$ diameter meter performance, matched the water demand profile given in Table 1, is $97.849 \%$ (i.e. $100-2.151$ ). If the flow rate exceeds the meter's maximum specified flow rate by more than $30 \%$, the error limit is assumed to be $100 \%$.

Application of this method can be illustrated by assuming that the new meter specified in Table 2 was the proposed replacement for an existing meter, whereby $50 \%$ of the volume of water measured by the existing meter was at $1.3 \mathrm{x} \mathrm{q}_{\mathrm{s}}$ and $50 \%$ at greater than $1.3 \mathrm{x} \mathrm{q}_{\mathrm{s}}$, which means a weighted accuracy of $47.5 \%$ (i.e. 100 $-(5 \times 0.5)-(50 \times 1))$ for the existing meter.

The new $80 \mathrm{~mm}$ diameter would provide a potential improvement in accuracy of $50.349 \%$ (i.e. 97.849 - 47.5).

The assumption also made is that the existing meter is in a suitable operating condition and without appreciable mechanical wear that could adversely affect the flow data captured by electronic monitoring and presented in Table 1.

\begin{tabular}{|c|c|c|}
\hline \multicolumn{3}{|c|}{$\begin{array}{c}\text { TABLE } 1 \\
\text { Percentage volume of water } \\
\text { per flow rate }\end{array}$} \\
\hline Time & $\begin{array}{l}\text { Flow } \\
\left(m^{3} / h\right)\end{array}$ & $\begin{array}{l}\% \text { of } \\
\text { total }\end{array}$ \\
\hline 0:00 & 0.30 & 0.02 \\
\hline 1:00 & 0.25 & 0.02 \\
\hline $2: 00$ & 0.28 & 0.02 \\
\hline $3: 00$ & 0.34 & 0.02 \\
\hline 4:00 & 0.45 & 0.03 \\
\hline 5:00 & 0.80 & 0.05 \\
\hline $6: 00$ & 5.00 & 0.33 \\
\hline 7:00 & 10.00 & 0.66 \\
\hline 8:00 & 50.00 & 3.29 \\
\hline $9: 00$ & 100.00 & 6.58 \\
\hline $10: 00$ & 120.00 & 7.90 \\
\hline 11:00 & 150.00 & 9.87 \\
\hline $12: 00$ & 135.00 & 8.88 \\
\hline 13:00 & 120.00 & 7.90 \\
\hline $14: 00$ & 110.00 & 7.24 \\
\hline $15: 00$ & 100.00 & 6.58 \\
\hline $16: 00$ & 80.00 & 5.27 \\
\hline $17: 00$ & 75.00 & 4.94 \\
\hline $18: 00$ & 90.00 & 5.92 \\
\hline $19: 00$ & 110.00 & 7.24 \\
\hline 20:00 & 135.00 & 8.88 \\
\hline 21:00 & 75.00 & 4.94 \\
\hline $22: 00$ & 40.00 & 2.63 \\
\hline 23:00 & 10.00 & 0.66 \\
\hline $24: 00$ & 2.00 & 0.13 \\
\hline Totals & $1519.42 \mathrm{~m}^{3}$ & $100.00 \%$ \\
\hline
\end{tabular}

If there is doubt as to the existing meter's ability to capture a true representation of the water demand pattern, then the existing old meter can be replaced by a new meter of the same size and model for the duration of an electronic logging exercise.

In the case of existing unmetered supply pipes, the initial sizing of the meter could be undertaken through the application of other modules of the meter selection system which are based on design codes and standards applicable to that particular country or region. On installation, this provisionally sized meter could then be electronically logged and sized according to the method described here.

The application of this methodology is most suited to, although not restricted to, single mechanical water meters rather than a combination water meters that has wide flow range capabilities.

\section{Energy cost}

The accuracy curve of a mechanical meter is also influenced by the resistance of the measuring mechanism to the flowing water. The energy head loss of water flowing through a turbine water meter can be defined by Eq. (i).

$$
\log (h)=M \log (q)+c
$$

where:

$$
\mathrm{h}=\text { head loss in metres of water (water gauge) }
$$




\begin{tabular}{|c|c|c|c|c|}
\hline \multicolumn{5}{|c|}{$\begin{array}{c}\text { TABLE } 2 \\
\text { Calculation of weighted accuracy }\end{array}$} \\
\hline $\begin{array}{c}(1) \\
\text { Reference }\end{array}$ & $\begin{array}{c}(2) \\
80 \mathrm{~mm} \text { diameter } \\
\text { performance } \\
\text { specification } \\
\left(\mathrm{m}^{3} / \mathrm{h}\right)\end{array}$ & $\begin{array}{l}\text { (3) } \\
\text { Error } \\
\text { limits (\%) }\end{array}$ & $\begin{array}{c}(4) \\
\text { \% Volume } \\
@ \text { flow rate }\end{array}$ & $\begin{array}{c}(5) \\
\text { Weighted } \\
\text { accuracy } \\
(\%)\end{array}$ \\
\hline \multirow[t]{2}{*}{$\begin{array}{l}\leq \text { Starting flow }(\mathrm{sf}) \\
\mathrm{sf}-\mathrm{q}_{\min } \\
\mathrm{q}_{\min }-\mathrm{q}_{\mathrm{t}} \\
\mathrm{q}_{\mathrm{t}}-\mathrm{q}_{\mathrm{p}}\left(\mathrm{q}_{\mathrm{n}}\right) \\
\mathrm{q}_{\mathrm{p}}-\mathrm{q}_{\mathrm{s}}\left(\mathrm{q}_{\max }\right) \\
\mathrm{q}_{\mathrm{s}}-1.3 \times \mathrm{q}_{\mathrm{s}}\end{array}$} & $\begin{array}{l}0.25 @ \mathrm{sf} \\
0.50 @ \mathrm{q}_{\min } \\
0.80 @ \mathrm{q}_{\mathrm{t}} \\
120.0 @ \mathrm{q}_{\mathrm{p}} \\
200 @ \mathrm{q}_{\mathrm{s}} \\
260 @ 1.3 \mathrm{q}_{\mathrm{s}}\end{array}$ & $\begin{array}{c}100 \\
15 \\
5 \\
2 \\
2 \\
5\end{array}$ & $\begin{array}{c}0.02 \\
0.09 \\
0.05 \\
72.21 \\
27.63 \\
0\end{array}$ & $\begin{array}{c}0.020 \\
0.014 \\
0.003 \\
1.444 \\
0.553 \\
0\end{array}$ \\
\hline & & & $\Sigma 100.00$ & $\Sigma 2.151$ \\
\hline $\begin{array}{l}\text { Notes: sf not } \\
\text { shown on Fig. } 1\end{array}$ & $\begin{array}{c}\text { From } \\
\text { Manufacturer's } \\
\text { Manual }\end{array}$ & From Fig. 1 & From Table 1 & $(3)^{*}(4) \div 100$ \\
\hline
\end{tabular}

variables, are interest rates, general economic conditions, consumer-demand patterns and so on. Together with the fact that the time horizon for some capital projects may extend far into the future, anticipating the time and benefit of these investment activities can be a highly uncertain process (The Economist, 1999).

The capital budgeting techniques commonly used to select a financially favourable project include payback period, NPV and IRR.

The payback period (Gitman, 1994) is the time required for an organisation to recover its initial investment in a project as calculated from cash inflows. The decision criterion is that if the payback is less than the maximum acceptable payback period set by the organisation, the project or parameters selected will be acceptable. If the payback period is greater than the maximum acceptable payback period, the project should be rejected or the parameters reviewed and, if desirable,

$\mathrm{q}=$ flow rate in $\mathrm{m}^{3} / \mathrm{s}$

$\mathrm{M}=$ slope constant

$\mathrm{c}=\mathrm{y}$ axis intercept $(\mathrm{m})$

Although the theoretical value for the coefficient (or exponent) for $\mathrm{M}$ is 2 (Miller, 1989), the actual coefficient derived from the manufacturer's brochures varies from 1.43 (for a Meinecke WPD250) to 2.36 (for a Meinecke WPD 40). The power required to overcome energy loss through the meter can be calculated with the aid of Eq. (ii).

$$
\mathrm{P}=\rho g q h
$$

where:

$$
\begin{aligned}
& \mathrm{P}=\text { power (Watt) } \\
& \mathrm{q}=\text { flow rate in } \mathrm{m}^{3} / \mathrm{s} \\
& \rho=\text { density of water }\left(\mathrm{kg} / \mathrm{m}^{3}\right) \\
& \mathrm{g}=\text { gravitational acceleration }\left(\mathrm{m} / \mathrm{s}^{2}\right) \\
& \mathrm{h}=\text { head loss given in equation }(\mathrm{i})(\mathrm{m})
\end{aligned}
$$

In many instances, the additional energy cost resulting from permanent pressure loss is a factor in flow meter selection. Pumping costs are sometimes significant in larger pipeline sizes and may justify the selection of a more expensive flow meter that either has a lower permanent pressure-loss coefficient or is obstructionless (Miller, 1989).

The average logged flow rate is used to establish the annual energy costs of the meter.

\section{Economic/financial analysis}

The potential annual revenue gained and energy costs reflect a part of the financial situation. For completeness it is desirable also to consider the financial suitability of an investment and to compare alternatives.

Capital budgeting techniques can be used to assist in the process of analysing and selecting appropriate long-term investment projects such as water meter installations. Factors determining a capital investment project's ultimate success are sometimes beyond an organisation's direct control. Such factors, known as exogenous be adjusted and the model run again.

The NPV (Gitman, 1994) considers the time value of money and is found by subtracting a project's initial investment from the present value of its cash inflows discounted at a rate equal to the organisation's cost of capital. The decision criterion is that if the NPV is greater than R0, the project or parameters selected should be acceptable; if NPV is less than R0, the project should be rejected or the parameters adjusted and the model run again.

The IRR (Gitman, 1994) is a capital budgeting technique that uses the cost of capital to consider the time factor in the value of money. It is the discount rate that equates the present value of cash inflows to the initial investment associated with a project, thereby causing NPV = R0. The decision criterion is that if the IRR is greater than the cost of capital, the project and the parameters selected should be acceptable. If the IRR is less than the cost of capital, the project should be rejected or the parameters reviewed and, if desirable, adjusted and the model run again.

When cash flows do not follow the conventional pattern of an initial cash outflow, followed by subsequent cash inflows (i.e. further net cash outflows in later years), no single unique IRR value can be determined. This is because of Descarte's rule which relates to the IRR root being the root of a polynomial equation which results in several different solutions when applied to unconventional cash outflows.

\section{Water meter selection system}

The application of a computerised optimal water meter selection system, incorporating the previously detailed theory, was undertaken with a sample of logged data from a Meinecke WP $100 \mathrm{~mm}$ diameter water meter. The meter was monitored continuously with the aid of electronic loggers for a period of more than $20 \mathrm{~d}$.

A time-interval of $15 \mathrm{~min}$ was selected for analysis of the logged data and the computer software identifying that a Meinecke WDP-100 mm would provide a $0.25 \%$ gain in accuracy. The performance specifications for these two meters are given in Tables 3 and 4 .

The software ranks the replacement meters in accordance with greatest weighted accuracy gain, lowest cost and within the selected energy head loss parameters. 
Seasonal correction of the water demand pattern can also be undertaken through the input of seasonal factors. These seasonal factors are applied to the demand profile, that might not have been measured in a peak season, to simulate a peak season demand profile measuring an increased volume of water. However, seasonal correction has been omitted from this example for the sake of simplicity.

A graphical representation of the two meter's error curves and volume usage at the various flow rates is given in Fig. 3.

The development of the software's economic/financial model was based on an income statement incorporating economic analysis. The model has three main components, viz. income, expenditure and economic analysis.

The income component assists in establishing the potential income from the increased sale of water as a result of the improved accuracy over a possible greater range of operation of the new meter. These sales would be adversely influenced by nonrecoverable leakage/wastage of water and/ or the probability of non-payment by the consumer(s).

The proportion of the water tariff that can be attributed to the recovery of the costs of the new meter and its installation can also be estimated using a probability factor as a proxy variable for a marginal tariff. When a water meter is installed in a pipeline that is part of a particular pumping system, then the energy costs should be taken into account. The new meter could generate less energy loss than the original meter installed in the system. The savings in energy costs as a result of the proposed meter should be reflected as an improvement in income.

The expenditure component assists in establishing the estimated costs associated with the proposed meter and its complete installation. The main cost items are the purchase price of the new meter as well as its installation costs. Other costs can include operating and maintenance costs, royalties and levies as well as taxes such as value added tax (VAT) or general sales tax (GST) that a water authority might have to charge for water sales. Operating and maintenance costs could include those costs incurred to clean in-line protection screens and for routine inspections. In determining the depreciation of a new meter, it is important to match the cost of the service capacity consumed with the income generated by the use of the asset. A fixed percentage of the total investment is recommended for simplicity. Depreciation, however, is a source of funds as it represents a "non-use" of funds and must be added to the net surplus (profit) after taxes.
TABLE 3

Calculation of weighted accuracy for existing WP 100 meter

\begin{tabular}{|c|c|c|c|c|}
\hline $\begin{array}{c}(1) \\
\text { Reference }\end{array}$ & $\begin{array}{c}(2) \\
80 \mathrm{~mm} \text { diameter } \\
\text { performance } \\
\text { specification } \\
\left(\mathrm{m}^{3} / \mathrm{h}\right)\end{array}$ & $\begin{array}{c}\text { (3) } \\
\text { Error } \\
\text { limits (\%) }\end{array}$ & $\begin{array}{c}(4) \\
\text { \% Volume } \\
@ \text { flow rate }\end{array}$ & $\begin{array}{c}(5) \\
\text { Weighted } \\
\text { accuracy } \\
(\%)\end{array}$ \\
\hline \multirow[t]{2}{*}{$\begin{array}{l}\leq \text { Starting flow }(\mathrm{sf}) \\
\mathrm{sf}-\mathrm{q}_{\min } \\
\mathrm{q}_{\min }-\mathrm{q}_{\mathrm{t}} \\
\mathrm{q}_{\mathrm{t}}-\mathrm{q}_{\mathrm{p}}\left(\mathrm{q}_{\mathrm{n}}\right) \\
\mathrm{q}_{\mathrm{p}}-\mathrm{q}_{\mathrm{s}}\left(\mathrm{q}_{\max }\right) \\
\mathrm{q}_{\mathrm{s}}-1.3 \times \mathrm{q}_{\mathrm{s}} \\
>1.3 \times \mathrm{q}_{\mathrm{s}}\end{array}$} & $\begin{array}{c}0.30 @ \mathrm{sf} \\
1.20 @ \mathrm{q}_{\min } \\
3.00 @ \mathrm{q}_{\mathrm{t}} \\
180 @ \mathrm{q}_{\mathrm{p}} \\
250 @ \mathrm{q}_{\mathrm{s}} \\
325 @ 1.3 \mathrm{xq}_{\mathrm{s}}\end{array}$ & $\begin{array}{c}100 \\
15 \\
5 \\
2 \\
2 \\
5 \\
100\end{array}$ & $\begin{array}{c}0.00 \\
0.00 \\
0.00 \\
48.59 \\
43.15 \\
8.26 \\
0.00\end{array}$ & $\begin{array}{l}0.000 \\
0.000 \\
0.000 \\
0.972 \\
0.863 \\
0.413 \\
0.000\end{array}$ \\
\hline & & & $\Sigma 100.00$ & $\Sigma 2.248$ \\
\hline
\end{tabular}

\begin{tabular}{|c|c|c|c|c|}
\hline \multicolumn{5}{|c|}{$\begin{array}{c}\text { TABLE } 4 \\
\text { Calculation of weighted accuracy for proposed WPD } 100 \text { meter }\end{array}$} \\
\hline $\begin{array}{c}(1) \\
\text { Reference }\end{array}$ & $\begin{array}{c}(2) \\
80 \mathrm{~mm} \text { diameter } \\
\text { performance } \\
\text { specification } \\
\left(\mathrm{m}^{3} / \mathrm{h}\right)\end{array}$ & $\begin{array}{c}(3) \\
\text { Error } \\
\text { limits (\%) }\end{array}$ & $\begin{array}{c}\text { (4) } \\
\text { \% Volume } \\
\text { @ flow rate }\end{array}$ & $\begin{array}{c}(5) \\
\text { Weighted } \\
\text { accuracy } \\
(\%)\end{array}$ \\
\hline \multirow[t]{2}{*}{$\begin{array}{l}\leq \text { Starting flow }(\mathrm{sf}) \\
\mathrm{sf}-\mathrm{q}_{\min } \\
\mathrm{q}_{\min }-\mathrm{q}_{\mathrm{t}} \\
\mathrm{q}_{\mathrm{t}}-\mathrm{q}_{\mathrm{p}}\left(\mathrm{q}_{\mathrm{n}}\right) \\
\mathrm{q}_{\mathrm{p}}-\mathrm{q}_{\mathrm{s}}\left(\mathrm{q}_{\max }\right) \\
\mathrm{q}_{\mathrm{s}}-1.3 \times \mathrm{q}_{\mathrm{s}} \\
>1.3 \times \mathrm{q}_{\mathrm{s}}\end{array}$} & $\begin{array}{c}0.25 @ \mathrm{sf} \\
0.80 @ \mathrm{q}_{\min } \\
1.80 @ \mathrm{q}_{\mathrm{t}} \\
230 @ \mathrm{q}_{\mathrm{p}} \\
300 @ \mathrm{q}_{\mathrm{s}} \\
390 @ 1.3 \mathrm{xq}_{\mathrm{s}}\end{array}$ & $\begin{array}{c}100 \\
15 \\
5 \\
2 \\
2 \\
5 \\
100\end{array}$ & $\begin{array}{c}0.00 \\
0.00 \\
0.00 \\
79.90 \\
20.10 \\
0.00 \\
0.00\end{array}$ & $\begin{array}{l}0.000 \\
0.000 \\
0.000 \\
1.598 \\
0.402 \\
0.000 \\
0.000\end{array}$ \\
\hline & & & $\Sigma 100.00$ & $\Sigma 2.000$ \\
\hline
\end{tabular}

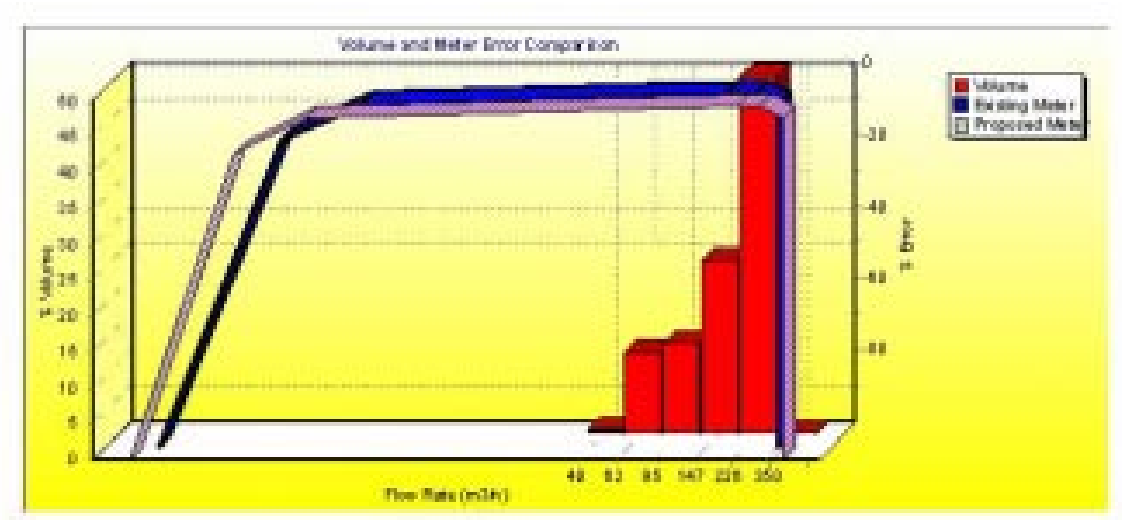

Figure 3

Meter comparison graph

Economic analysis is used to appraise whether the investment in the new water meter is feasible or not and whether it can produce an optimal surplus (marginal cost $=$ average cost) in years to come. The capital budgeting techniques included in the software include the previously described payback period, NPV and IRR.

Application of the software model in the analysis of the assumed data for the cost of a WPD 100 replacement water meter, a 9\% per annum cost of capital, a 15\% tax rate as 
TABLE 5

Economic/financial analysis report

\begin{tabular}{|c|c|c|c|c|c|c|c|c|c|c|}
\hline & \multicolumn{10}{|c|}{ Yearly breakdown of economic analysis factors } \\
\hline & $\begin{array}{c}\text { Base Year } \\
2000\end{array}$ & $\begin{array}{c}\text { Year } 2 \\
2001\end{array}$ & $\begin{array}{l}\text { Year } 3 \\
2002\end{array}$ & $\begin{array}{c}\text { Year } 4 \\
2003\end{array}$ & $\begin{array}{c}\text { Year } 5 \\
2004\end{array}$ & $\begin{array}{l}\text { Year } 6 \\
2005\end{array}$ & $\begin{array}{l}\text { Year } 7 \\
2006\end{array}$ & $\begin{array}{c}\text { Year } 8 \\
2007\end{array}$ & $\begin{array}{c}\text { Year } 9 \\
2008\end{array}$ & $\begin{array}{c}\text { Year } 10 \\
2009\end{array}$ \\
\hline $\begin{array}{l}\text { Total number of meters } \\
\text { Average annual usage }\left(\mathrm{m}^{3}\right) \\
\text { Estimated annual water sales }\left(\mathrm{m}^{3}\right) \\
\text { Improvement in accuracy over existing meter }(\%) \\
\text { Tariff }\left(\mathrm{R} / \mathrm{m}^{3}\right) \\
\text { Probability of income }(\%)\end{array}$ & $\begin{array}{c}1 \\
1182008 \\
919208 \\
0.25 \\
1.50 \\
95\end{array}$ & $\begin{array}{c}1 \\
1182008 \\
919208 \\
0.25 \\
1.50 \\
95\end{array}$ & $\begin{array}{c}1 \\
1182008 \\
919208 \\
0.25 \\
1.50 \\
95\end{array}$ & $\begin{array}{c}1 \\
1182008 \\
919208 \\
0.25 \\
1.50 \\
95\end{array}$ & $\begin{array}{c}1 \\
1182008 \\
919208 \\
0.25 \\
1.50 \\
95\end{array}$ & $\begin{array}{c}1 \\
1182008 \\
919208 \\
0.25 \\
1.50 \\
95\end{array}$ & $\begin{array}{c}1 \\
1182008 \\
919208 \\
0.25 \\
1.50 \\
95\end{array}$ & $\begin{array}{c}1 \\
1182008 \\
919208 \\
0.25 \\
1.50 \\
95\end{array}$ & $\begin{array}{c}1 \\
1182008 \\
919208 \\
0.25 \\
1.50 \\
95\end{array}$ & $\begin{array}{c}1 \\
1182008 \\
919208 \\
0.25 \\
1.50 \\
95\end{array}$ \\
\hline $\begin{array}{l}\text { Income component } \\
\text { Income from annual potential revenue gained } \\
\text { Annual energy saving/loss(-) } \\
\text { Total income }\end{array}$ & $\begin{array}{c}3275 \\
548.07 \\
3823\end{array}$ & $\begin{array}{c}3275 \\
548.07 \\
3823\end{array}$ & $\begin{array}{c}3275 \\
548.07 \\
3823\end{array}$ & $\begin{array}{r}3275 \\
548.07 \\
3823\end{array}$ & $\begin{array}{c}3275 \\
548.07 \\
3823\end{array}$ & $\begin{array}{c}3275 \\
548,07 \\
3823\end{array}$ & $\begin{array}{c}3275 \\
548,07 \\
3823\end{array}$ & $\begin{array}{c}3275 \\
548,07 \\
3823\end{array}$ & $\begin{array}{c}3275 \\
548,07 \\
3823\end{array}$ & $\begin{array}{r}3275 \\
548,07 \\
3823\end{array}$ \\
\hline $\begin{array}{l}\text { Expenditure component } \\
\text { Royalties and levies } \\
\text { Operating and maintenance cost } \\
\text { Other annual expenditure } \\
\text { Surplus or deficit before depreciation } \\
\text { Depreciation } \\
\text { Surplus or deficit before tax } \\
\text { Tax } \\
\text { Surplus or deficit } \\
\text { Surplus or deficit + depreciation } \\
\text { Absorption of investment fund } \\
\text { Cumulative investment }\end{array}$ & $\begin{array}{c}0.00 \\
800 \\
0.00 \\
3023 \\
1050.00 \\
1973 \\
296 \\
1677 \\
2727 \\
10500.00 \\
10500\end{array}$ & $\begin{array}{c}0.00 \\
800 \\
0.00 \\
3023 \\
1050.00 \\
1973 \\
296 \\
1677 \\
2727 \\
0.00 \\
10500\end{array}$ & $\begin{array}{c}0.00 \\
800 \\
0.00 \\
3023 \\
1050.00 \\
1973 \\
296 \\
1677 \\
2727 \\
0.00 \\
10500\end{array}$ & $\begin{array}{c}0.00 \\
800 \\
0.00 \\
3023 \\
1050.00 \\
1973 \\
296 \\
1677 \\
2727 \\
0.00 \\
10500\end{array}$ & $\begin{array}{c}0.00 \\
800 \\
0.00 \\
3023 \\
1050.00 \\
1973 \\
296 \\
1677 \\
2727 \\
0.00 \\
10500\end{array}$ & $\begin{array}{c}0.00 \\
800 \\
0.00 \\
3023 \\
1050.00 \\
1973 \\
296 \\
1677 \\
2727 \\
0.00 \\
10500\end{array}$ & $\begin{array}{c}0.00 \\
800 \\
0.00 \\
3023 \\
1050.00 \\
1973 \\
296 \\
1677 \\
2727 \\
0.00 \\
10500\end{array}$ & $\begin{array}{c}0.00 \\
800 \\
0.00 \\
3023 \\
1050.00 \\
1973 \\
296 \\
1677 \\
2727 \\
0.00 \\
10500\end{array}$ & $\begin{array}{c}0.00 \\
800 \\
0.00 \\
3023 \\
1050.00 \\
1973 \\
296 \\
1677 \\
2727 \\
0.00 \\
10500\end{array}$ & $\begin{array}{c}0.00 \\
800 \\
0.00 \\
3023 \\
1050.00 \\
1973 \\
296 \\
1677 \\
2727 \\
0.00 \\
10500\end{array}$ \\
\hline $\begin{array}{l}\text { Total cost of new meter installed: R10 } 500.00 \\
\text { Cost of capital: } 9 \% \\
\text { Costs incurred in the first year } \\
\text { Accuracy/age deterioration of meter: } 0 \% \text { per year } \\
\text { Depreciation of meter spread over } 10 \text { years } \\
\text { Energy cost: R0.25 kW.h }\end{array}$ & \multicolumn{10}{|c|}{$\begin{array}{ll}\text { Payback period: } & 4 \text { years } \\
\text { Net present value: } & \text { R14 900.06 } \\
\text { Return on investment: } & 15.97 \%\end{array}$} \\
\hline
\end{tabular}




\begin{tabular}{|c|c|c|c|}
\hline \multicolumn{4}{|c|}{$\begin{array}{c}\text { TABLE } 6 \\
\text { Sensitivity analysis }\end{array}$} \\
\hline \multirow[t]{2}{*}{ Changes to original inputs to Table 5} & \multicolumn{3}{|c|}{ Results } \\
\hline & $\begin{array}{c}\text { Payback } \\
\text { period (yrs) }\end{array}$ & ROI (\%) & NPV (R) \\
\hline As per Table 5 (no changes) & 4 & 15.97 & 14900 \\
\hline Accuracy/age deterioration $=0.01 \% / \mathrm{yr}$ & 5 & 11.20 & 11708 \\
\hline Annual energy saving $=\mathrm{R} 0$ & 5 & 11.53 & 11383 \\
\hline Water tariff doubled to $\mathrm{R} 3 / \mathrm{m}^{3}$ & 2 & 42.48 & 35916 \\
\hline Depreciation period $=5 \mathrm{yrs}$ & 4 & 7.47 & 5236 \\
\hline
\end{tabular}

well as the probability of income of $95 \%$ indicates that the project is economically viable as illustrated in the results in Table 5 . An annual operating and maintenance cost of R800 and the loss of revenue due to a measured nett minimum night flow of $30 \mathrm{~m}^{3} / \mathrm{h}$ indicate that the total costs of new meter installation will pay for itself within 4 years and generate a return on investment of nearly $16 \%$.

Although the initial (arbitrary) depreciation period was selected as 10 years, subsequent sensitivity analysis illustrated in Table 6 indicates that a 5-year depreciation period to be more suitable.

A sensitivity analysis of the original scenario depicted in Table 5 was undertaken through the re-application in turn of various variables to this original scenario. The results of this analysis are given in Table 6 .

If allowance is made for the deterioration in the accuracy of the new meter of $0.01 \%$ per year, which would result in a reduced accuracy gain over the existing meter over time, then the payback period is increased by 1 year to 5 years. If the meter was not part of a pumping system, then the energy costs/savings would be zero and payback period would also increase from the original 4 years to 5 years. A doubling of the water tariff from R $1.50 / \mathrm{m}^{3}$ to R $3 / \mathrm{m}^{3}$ would reduce the payback period by 2 years in this example.

\section{Concluding remarks}

The incorrect matching of a particular water meter performance with the demand characteristics of a consumer can result in the loss of revenue to a water authority. The estimation of the amount that this loss can be reduced to due to the correct selection of a replacement meter can justify the selection process.

The matching of a particular meter accuracy envelope and a consumer's water demand/usage profile through weighted accuracies play a pivotal role in these comparisons with a common reference.

Economic/financial analysis based on an income statement together with capital budgeting techniques assists in determining the financial suitability of the proposed investment in the replacement meter and its installation. Sensitivity analysis facilitated the identification of which variables influence the economical viability of installing a new water meter.

\section{Acknowledgement}

Appreciation is expressed for permission given to publish this article by Basil Bold, the Managing Director of Meinecke Meters (Pty) Ltd.

\section{References}

AMERICAN WATER WORKS ASSOCIATION (1975) Sizing Water Service Lines and Meters. Manual of Water Supply Practices.

AMERICAN WATER WORKS ASSOCIATION (1985) Water Sources and Transmission. Principles and Practices of Water Supply Operations.

BRITISH STANDARDS INSTITUTION BS6700 (1987) Design, Installation, Testing and Maintenance of Services Supplying Water for Domestic Use Within Buildings and their Curtilages.

BRITISH STANDARDS INSTITUTION BS7405 (1991) Selection and Application of Flow Meters for the Measurement of Fluid Flow in Closed Conduits.

BOOYENS JD (2000) Spitsvloei in Munisipale Waterverspreidingnetwerke. M.Eng. in Civ. Eng. Rand Afrikaans Univ.

BUCHBERGER SG and WELLS GJ (1996) Intensity, duration and frequency of residential water demands. J. of Water Resour. Plan. and Manage. (January/February) 11-19.

COE AL (1978) Water Supply and Plumbing Practices in Continental Europe. Hutchinson Benham, London.

DEPARTMENT OFCOMMUNITY DEVELOPMENT (1983) Guidelines for the Provision of Engineering Services in Residential Townships (Blue Book). Prepared by the CSIR.

DEPARTMENT OF PLANNING, PROVINCIAL AFFAIRS AND HOUSING (1991) Guidelines for the Provision of Engineering Services and Amenities in Residential Township Development (Red Book). Prepared by the Division of Building Technology, CSIR.

GITMAN LJ (1994) Principles of Managerial Finance. Harper Collins College Publishers.

INTERNATIONAL ORGANISATION FOR STANDARDISATION (1993) Measurement of Water Flow in Closed Conduit Meters for Cold Potable Water (ISO 4064) Part 1: Specifications.

JEFFCOATE P and POND R (1989) Large water meters: Guidelines for Selection, Testing and Maintenance. World Bank Technical Paper Number III.

JOHNSON EH (1987) Flow Data Acquisition and Forecasting System for a Water Distribution Network. Laureatus Thesis (now known as a Doctorate in Technology), Port Elizabeth Technikon.

JOHNSON EH (1999) Degree of utilisation - The reciprocal of the peak factor. Its application in the operation of a water supply and distribution system. Water SA 25 (1) 111-114.

LINAWEAVER FP, GEYER JC and WOLFF JB (1967) A Study of Residential Water Use. John Hopkins Univ., Baltimore, Maryland.

MALAN GJ (1983) Water Economy-The Worthwhile Goal. NBRI Report R/Bou 1195.

MEINECKE W (1984) Measuring Characteristics of Water Meters Aqua No. 4. Pergamon Press Ltd. 233 - 237.

MILLER RW (1989) Flow Measurement Handbook. McGraw-Hill.

SCHLEMMER L, STEWART G and WHITTLES J (1969) The SocioEconomic Effects of Water Restrictions on Local Authorities, Selected Industrial and Commercial Establishments and other Private Agencies. WRC Report No 68/1/89. 
SIMPSONGC(1989) Development and Testing of Data Logging Equipment for the Monitoring of Water Consumption Patterns. WRC Report No 255/1/90.

SOUTH AFRICAN STANDARD SPECIFICATION SABS 0252-1 (1994) Code of Practice Part 1: Water Supply Installations for Buildings.

SOUTH AFRICAN STANDARD SPECIFICATION SABS 1529-1 (1994) Water Meters for Cold Potable Water, Part 1: Metrological Characteristics of Mechanical Water Meters of Nominal Bore not Exceeding 100 $\mathrm{mm}$.

TESSENDORFF H (1972) Problems of peak demands and remedial measures. Proc. $9^{\text {th }}$ Congr. Int. Water Supply Assoc. Int. Standing Comm. on Distrib. Probl. : Subject no. 2 S10-S14.
THE ECONOMIST (1999) Keeping all options open (14 August) 62. TURNER RH, FOWLER TG, MANSON NJ and STEPHENSOND (1997) Optimisation of Rand Water's Distribution System. WRC Report No 488/1/97.

VAN SCHALKWYK A (1996) Guidelines for the Estimation of Domestic Water Demand of Developing Communities in the Northern Transvaal. WRC Report No 480/1/96.

WILD RD (1997) The Performance, Selection and Optimum Replacement Interval of Water Meters. Dissertation for Masters Diploma in Technol. Port Elizabeth Technikon. 